Published by the UFS

http://journals.ufs.ac.za/index.php/trp

(c) Creative Commons With Attribution (CC-BY)

How to cite: Verster, B. 2020. Reimagining collaboration in urban planning through a social practice

lens: Towards a conceptual framework. Town and Regional Planning, no.76, pp. 86-96.

\section{Reimagining collaboration in urban planning through a social practice lens: Towards a conceptual framework}

\section{Belinda Verster}

\section{DOI: http://dx.doi.org/10.18820/2415-0495/trp76i1.7}

Peer reviewed and revised February 2020

Published June 2020

*The authors declared no conflict of interest for this title or article

\begin{abstract}
Collaboration manifests in urban planning as central to all public engagement activities and is thus a powerful tool in the planner's quest for social justice and empowered societies. This being said, as a foundational urban planning concept, collaboration has been influenced by neoliberal and technocratic tendencies and as such has become identifiable as a skill (a way of doing) rather than its intended normative character (a way of being). This article represents an effort to reframe and reimagine a contextually sensitive understanding of collaboration, by proposing a conceptual framework based on theoretical perspectives from two distinct subject areas, namely social practice and collaborative urban planning. This article further introduces a 'relational reading of text' as an alternative form of research method or inquiry to explore collaboration. Through this method, five social practice dimensions emerged. It is contended that these five dimensions, namely relational actions, entities, sense-making, interrelatedness, and structuring tensions can refocus the worth of collaboration as a professional value attribute for both students of urban planning and practitioners.
\end{abstract}

Keywords: Collaboration, collaborative planning theory, relational reading of text, social practice theory

\section{HEROORDINK SAMEWERKING IN STEDELIKE BEPLANNING DEUR 'N MAATSKAPLIKE PRAKTYKLENS: 'N KONSEPTUELE RAAMWERK}

Samewerking in stedelike beplanning is sentraal tot alle openbare betrokkenheidsaktiwiteite en is dus 'n kragtige instrument in die beplanner se soeke na sosiale geregtigheid en bemagtigde samelewings. Samewerking as 'n fundamentele stedelike beplanningskonsep word beïnvloed deur neoliberale en tegnokratiese neigings en kan as sodanig geïdentifiseer word as 'n vaardigheid ('n manier van doen) eerder as die beoogde normatiewe karakter ' $n$ manier van wees). Hierdie artikel poog om 'n kontekssensitiewe begrip van samewerking in 'n nuwe raam te plaas en weer daaroor te dink, deur 'n konseptuele raamwerk voor te stel gebaseer op teoretiese perspektiewe uit twee verskillende vakgebiede: Sosiale praktyk en samewerkende stedelike beplanning. Hierdie artikel stel 'verhoudingslees van teks' voor as 'n alternatiewe navorsingsmetode om samewerking te ondersoek. Vyf sosiale praktykdimensies is deur middel van hierdie metode geïdentifiseer. Dit word aangevoer dat hierdie vyf dimensies, naamlik verhoudingsaksies, entiteite, sinmaak, interverwantskap en die strukturering van spanning die waarde van samewerking kan herfokus, as 'n professionele waarde-kenmerk, vir stedelike beplanningstudente en praktisyns.

Sleutelwoorde: Gesamentlike beplanningsteorie, samewerking, sosiale praktykteorie, verhoudingslees van teks

\section{HO NAHANISISA TŠEBELISANO MMOHO MERALONG EA LITOROPO KA LEIHLO LA LITLOAELONG TSA SECHABA: RE EA MORALONG OA KHOPOLO}

Tshebelisano mmoho meralong ea litoropo e bohlokoa mesebetsing eohle ea ts'ebetso ea sechaba ka hona ke sesebelisoa se matla sa ba ralang litoropo molemong oa ho tlisa toka le ho matlafatsa sechaba. Ka lebaka lena, tshebelisano 'moho joaloka mohopolo oa motheo oa ho rala litoropo o susumelitsoe ke litšekamelo tsa morao-rao tsa mahlale le lisebelisoa mme ka lebaka leo e tsebahala e le bokhoni (mokhoa oa ho etsa) ho fapana le sebopeho se tloaelehileng (boleng ba sona). Sengoloa sena se bontsha boiteko ba ho nahana le ho hlophisa bocha kutloisiso e tebileng ea ts'ebelisano mmoho ka ho fana ka maikutlo a moralo o thehiloeng ka maikutlo a tsoang libakeng tse peli tse ikhethileng: Litloaelo tsa sechaba le thero e kopanetsoeng ea litoropo. Sengoloa sena se boetse se hlahisa 'palo ea lingoliloeng tse amanang' e le mokhoa o mong oa ho etsa lipatlisiso ele ho hlahlobisa mohopolo oa tshebelisano mmho. Ka mokhoa ona, mekhoa e mehlano ea boits'oaro ba sechaba e ile ea hlahella. Ho phehisanoa ka hore likarolo tsena tse hlano, e leng liketso tse hlahisoang ke likamano tsa batho, mekhatlo, meelelo, likamano le le ho hlophisa likhohlano, li ka hlakisa bohlokoa ba tshebelisano mmoho ele boleng ba botsebi haholo ho barutoana le litsebi tsa thero ea litoropo.

\section{INTRODUCTION AND CONTEXTUALISATION}

The changing landscape of society warrants a continuous reconsideration of the profession of urban planning. One concern when considering urban planning practice is the general assumption that urban planners are naturally collaborative practitioners without explicitly foregrounding professional value attributes such as collaboration. This is believed to be problematic, as collaboration is considered fundamental in developing abilities to negotiate current and future societal complexities and changes (McCan, 2001: 216). 
The argument presented in this article is that urban planners need to focus attention on professional value attributes in their practices and in educating urban planning students. The reason for this stance is that value attributes could equip the planner (Carmon, 2013) in responding, in a meaningful and sustainable manner, to complex and dynamic shifts within the socio-eco ${ }^{1}(n)^{2}$-political landscape. One such complexity that holds special reference, in this instance, is the positioning of urban planners between society (communities and citizens) and state (decisionmakers and holders of power), or what Watson (2014: 62) refers to as "processes of state-society engagement". As a response to this complexity, the article focuses on collaboration as one of the threshold concepts in urban planning.

The focus on professional value attributes stems from what Carmon (2013: 14) describes as urban planning having an "action orientation [as well as] a value orientation". A refocusing towards the "value orientation" is called for in this article as the "action orientation", through neoliberal tendencies, seems to have been a driving force in cities (Goldfrank \& Schrank, 2009; Parnell \& Robinson, 2012). This neoliberal position is challenging the urban planning ethos of the "concern for the public interest" (Carmon, 2013: 18) or the common good (Friedman, 2000). The logic being followed, in this instance, is that professional value attributes and specifically collaboration as an embodiment of the common good are central to responding to neoliberal and market forces that are driving urban decision-making.

In order to conceptualise a highly complex and abstract issue such as a professional value attribute, this article disentangles and makes visible some elements (dimensions) that could assist in unpacking collaboration as a social practice in urban planning. This is done by

\footnotetext{
1 Ecological.

2 Economical.
}

proposing a conceptual framework that suggests issues (dimensions) that could be considered, discussed, negotiated and decided on as part of a collaborative endeavour. The conceptual framework intends to foreground issues that might otherwise be left behind or assumed.

\section{RESEARCH METHOD: A 'RELATIONAL READING OF TEXT' APPROACH}

This article follows an approach of engaging with text ${ }^{3}$ in what is described and developed, in this instance, as a relational reading of text. The major motivation for a relational reading of text approach was an attempt to move away from the traditional method of engaging with literature, text and theory in a 'to extract and/or compare' mode. It is essential to develop abilities and methods that expand the current research practices, and a relational reading is offered as one such an attempt. The relational reading of text method draws on diffraction (Haraway, 1992; Barad, 2007; 2014), a well-established research method that recognises a postqualitative positioning and focuses attention on "avoiding prescription and a rush to application" (Murris \& Bozalek, 2019: 2). A relational reading attempts to recognise and foregrounds the non-linear and entangled reality of engaging with text. Relational reading is, as diffraction, different to a "literature review as the latter assumes that you are at a distance of the literature, having a bird's eye point of view - creating an overview by comparing, contrasting, juxtaposing or looking for similarities and themes" (Murris \& Bozalek, 2019: 2). Certain epistemological deviations from diffraction were experienced and necessitated the development of a relational reading. Some of the major deviations are, among others, the relevance of pre-existing knowledge and the questioning of the "material discursive ... to lack independent, selfcontained existence" (Barad, 2007: xi).

\footnotetext{
3 Text is considered to include all reference sources of a textual nature. This article focuses on theory as text.
}

The material discursive does not recognise the need or the value to disentangle or focus on independent elements. This quality of diffraction thus goes against what this article sets out to accomplish. This article also recognises and draws from relevant pre-existing knowledge.

A relational reading is proposed to suppose that nothing exists in isolation and that things (be they objects, understanding, knowing, and so on) exist in a continuous relationality. To locate this engagement with text, the essential premise of relational theory as 'meaningful as relative to other' or 'meaning in terms of other' (Donati, 2010) is drawn on. It should be noted that text, in this article, is represented by theory.

The primary objective of a relational reading is to enable texts to be read alongside each other in a relational manner, instead of placing texts in opposition to each other. A wellestablished academic practice is to critique, thus finding differences, as a way of engaging with text. A relational reading is not a critique.

In essence, the focus of a relational reading is not so much the points of differences and/or affinities between texts, but how they influence each other to show alternatives or the 'new'. A relational reading adds value to a study of this nature, because it challenges conformity and allows new conceptions to emerge.

For purposes of this article, the characteristics or nuances of a relational reading of text (in this case, theory) as it emerged through Costandius' Flow Exercise (2019) is proposed and considered. These four characteristics of a relational reading provide an opportunity for researchers to be sensitive to how they engage with text.

\subsection{A sense of movement}

A relational reading of theory has a number of movement elements that depict direction, such as moving forward through arguments/ positions or differing theories moving in the same direction. It further 
represents continuity and flow where the restrictions of sameness and/or difference do not obscure the emergence of meaning. This emergence of meaning has a leadingto-the-next quality, which is a further directional indication. Law (2004: 104) states that, as researchers, "we are not good at thinking movement" when he describes the research skills we develop as "fixed and static, the separate and self-contained". Through a relational reading of theory, an attempt is made to respond to the 'fixed and static' and to move away from predictable, safe binaries such as the typical 'arguments for or against'.

\subsection{Shift to the in-between space of meaning}

Reference is being made to the in-between as that space where the 'a-ha' moment and new understandings are crafted. The inbetween holds a special richness of meaning as the focus moves to the emergence of new insights. Although the in-between is considered a spontaneous space, it is still held by structure. A structure can be provided, for example, by predetermining the text or theories with which we are engaging. The idea of the in-between is to move further away from the obvious; to focus our attention on what lies between the proverbial inside and outside. Part of what is deemed the in-between is to 'hear' the writer's voice. Simon (2012: par. 3) refers to this quality as "the writer renders her- or himself visible".

\subsection{The quality of kindred}

Kindred should not be misinterpreted as meaning sameness. It assumes a sense of belonging, a togetherness, an affinity with the text or theory. From this perspective, it is most probable that the quality of kindred closely resembles the concept of relationality through its focus on 'being in relation to'. Gergen (2008: 1) alludes to this quality of 'being in relation to' when he states that "writing is fundamentally an action within a relationship; it is within relationships that writing gains its meaning and significance". This quality merges the 'in-between' with the 'quality of kindred' in that it makes reference to the relation between writing and reading, writer and reader, and how meaningmaking is suspended in-between.

\subsection{Shared responsibility}

Responsibility has a power quality to it and would imply flattening power between the different texts and the relationship between theorist/writer and reader. A relational reading allows responsibility to be shared and provides the opportunity for empowerment. Orlikowski and Scott (2015: 3) make reference to "an ethic of reading and writing that turns away from excessive critique" to explain the shared responsibility that should exist within a relational reading of text. This quality renders the reader an ally in the meaning-making process.

The most important message for relational readers of text, it is argued, is to be aware of the expectations with which we enter the relational engagement. If it is to extract or compare, then that is what will emerge. If it is to let the text be in conversation with other texts and with the reader, then a relational reading demands a change in attitude.

\section{3. 'RELATIONAL READING OF TEXT' RESULTS}

By integrating the theories read, a descriptive relational perspective, in two iterations, is presented. The first iteration resulted in five social practice dimensions. This was further developed in the second iteration with the enrichment of collaborative planning theories. The five social practice dimensions (iteration 1) together with the sub-dimensions (iteration 2) are considered for inclusion in building the 'Collaboration as a Social Practice' (CoSoP) conceptual framework.

\subsection{Iteration 1: Social practice theories and resultant dimensions}

Social practice theory is considered an appropriate lens because of its lineage from theorists such as Bourdieu, Giddens, Taylor, and Foucault. The association of social practice theory with specifically Foucault has relevance, as Foucault foregrounds power that forms an essential part of collaboration, especially within the neoliberal context (Flyvbjerg, Richardson, Allmendinger \& Tewdwr-Jones, 2002: 44).

\subsubsection{Social practice dimension 1: Relational actions}

Schatzki (2005: 52) explains actions or activities within social practice as "systematically and interrelatedly meaningful". Actions thus do not stand in separation, but in combination with each other and the broader context. He argues that "practice is first a set of actions ... the performance of doings and sayings amounts ... to the carrying out of actions" (Schatzki, 2005: 56). Actions (taken together or alone by agents in a practice) are considered, in this instance, as the initiators of practice; thus, practice will be known or identifiable by its actions.

Reckwitz (2002: 244-249) shares this sentiment and elaborates by referring to types of behaviour that are interconnected to "form structures of action". Reckwitz alludes to the fact that actions are not singular but lead to more actions within a practice, forming strings or structures of action. This is an important characteristic of social practice that ensures its longevity, as action results in more action. Relational actions, in this sense, refer to the relations not only between agents of a practice, but also between the actions or activities.

Sager (2012: 27) provides useful insights with regard to understanding relational actions by referring to "relational goods". Relational goods are explained as those things that support (interpersonal) relations, "public goods that are simultaneously produced and consumed in relationships between people" (Sager, 2012: 27). Examples are social approval, friendship, confirmation of identity, emotional support, a sense of belonging, and solidarity. These can be viewed as 
the glue that holds the relational actions in social practices.

\subsubsection{Social practice dimension 2: Entities}

Entities should be considered in their broadest application, by viewing them both as materials to be used in social practice and as objects that are "known and interpreted ... objects of the knowing subject" as Reckwitz (2002: 253) explains it.

Boud and Brew (2017: 80) refer to "material mediation" when explaining the "materials and material arrangements" that constitute a practice. Materials and objects are considered to be physical resources and artefacts that either enable or limit a practice.

Kemmis, Wilkinson, EdwardsGroves, Hardy, Grootenboer and Bristol (2014) borrow from Schatzki's (2002: xi) understanding of social practice as a "nexus of arranged things and organised activities". Kemmis et al. (2014: 33) refer to entities in a practice as "resources found in or brought to the site: cultural-discursive resources, material-economic resources, and social-political resources". As with Boud and Brew's understanding, these have physical substance.

Kemmis et al. (2014: 29) further propose three distinguishable sets of things (entities): 'material', 'semantic' and 'social' things. Material things are understood to be things that can be touched or that carry a specific material value such as their weight, height, volume, and so on. Semantic things are "the languages and special discourses that shape the ways we interpret the world".

Boud and Brew (2017: 80) refer to "embodiment" as implied in a practice. Embodiment is understood to be "what people do, when and where ... people's identities and their sense of agency ... people bring their desires, emotions and values to be part of the practice".

Of importance are the centrality of the self and the recognition of the agent in practice theory, not only as an object or casualty of the social, but also as an active and essential determining factor. The understanding of the "individual as a crossing-point of different social spheres" (Simmels in Reckwitz, 2002: 260) needs to be considered in collaboration.

Lave (in Illeris, 2009: 200) refers to the "distractingly material, historically constituted, subjectively selective character of space-time relations and their meaning" when referring to the situatedness of practice. Situatedness or context, it is argued, is thus determined by the entities in/of practice. Wenger (1998: 6) highlights the fact that practices are all around us and located "officially or in the cracks". These "cracks" or the behind-the-scenes activities are of special interest to this research project, as they represent the so-called hidden curriculum in which, we assume, developing professional value attributes occurs.

Entities can be viewed as either limiting or expanding a social practice. An example of an entity that limits a practice would be a case where new knowledge production is low within a practice. Reasons for this scenario are manifold, but one that has relevance to this study might be the business-as-usual approach ${ }^{4}$ in a practice (Tasan-Kok \& Oranje, 2018).

Agents (entities) in a practice might be comfortable with what they know and how they know it. Reckwitz (2002: 251) warns that "we learn to be bodies in a certain way". A question that emerges is: Who teaches us to be agents or bodies in a practice and how are we taught?

In urban planning, 'context' is one of the fundamental determinants of any decision-making process. For this reason, context and the power it holds are foregrounded in urban planning practice and urban planning education. It goes without saying that social practice, as a relevant and applicable theory, should make reference to context.

When considering the context or setting of entities, Schatzki (2005: 54) provides some insights: "Practices

4 An approach that is not responsive to shifts. are context where actions are carried out ... practices as site and not just activity". Site would imply its location in relation to and with others.

Boud and Brew (2017: 77) take this sequence of thought further, by referring to "adaptation to context". Thus, if collaboration is context specific and so sensitive to context, adaptation and renewal are inevitable, if collaboration as a planning ability should hold its power to negotiate change.

\subsubsection{Social practice dimension 3: Sense-making}

Schatzki (1988: 244) refers to practical intelligibility or intelligibilitydetermining factors as those aspects or phenomena within a practice that determine what actors find sensible to do and engage with. He provides guidance, by explaining: "Now, what makes sense to a person to do is determined by a range of what can be called 'intelligibility determining factors': ends, ideas (including concepts and thoughts), mattering, knowledge, tasks and projects, rules, paradigms, customs, and setting" (Schatzki, 1988: 245).

Schatzki, Knorr-Cetina and Von Savigny (2005: 55) refer to practical intelligibility as "[h]ow things matter". When considering the "how things matter" quality, it should be noted that the statement is not 'which things matter'. By asking 'how', the focus is shifted to "how did it come to matter" in a social practice? Understanding the lineage of how things matter provides insight into relevance and significance.

Schatzki et al. (2005: 17) warn that "practice understanding cannot be adequately formulated in words ... either by social investigators or ... by actors themselves" when they explain the complexity of the hidden 'goings on' in a practice. The concern seems not to be with words as a form of expression, but rather the expression itself (representation), that some things within a practice cannot be expressed or quantified. Agents of a practice might not even be aware of its presence. 
It should be noted that sense-making applies not only to the agent in a social practice, but also to the "potential observers" within the same practice (Reckwitz, 2002: 250). The action and 'way of being' should not simply make sense to the person 'doing', but also to the person seeing it being done. There is thus buy-in that it is the appropriate way to be within a specific social practice.

All of the above is captured and influenced by what Boud and Brew (2017) refer to as 'embodiment'. Embodiment refers to the notion that "people bring their desires, emotions and values to be part of a practice" (Boud \& Brew, 2017: 80). Two questions then arise: To what extent does the practice influence, shape and develop these desires, emotions and values? On the other hand, how far does the individual agent shape the practice? Kemmis et al. (2014: 2) refer to "a dance between identity and otherness, a dance between the reproduction of some things alongside the transformation of others" to capture the fact that "change is happening all the time" and that change is reciprocal.

An idea that is embedded in sensemaking, but that, to some extent, also transcends it to influence the dimension of structuring tensions, is what Kelly (2002: 92) calls "society intent". Society intent refers to Reckwitz's (2002) 'social ought to' as a moral awareness and once more foregrounds the significance of professional value attributes.

\subsubsection{Social practice dimension 4: Interrelatedness}

Schatzki (1988: 247) states that "social reality consists [resides] in interrelated ongoing lives" to explain the centrality of interrelatedness. He provides insight into the main types of interrelations, by focusing, first, on that which is common in actors or groups, thus what binds them together. Secondly, he suggests that interrelatedness should be people-centred, by focusing on the relation between individuals and/or groups. A final influence on interrelatedness is the setting or context. In this instance, Schatzki (1988) understands the setting not to be only the physical, but to include, for example, a change in attitude or shifts in power relations. Kemmis et al. (2014: 4) refer to 'intersubjective spaces' when explaining the setting in which people encounter each other. This 'intersubjective space', similar to Schatzki's understanding, refers to "language ... space-time in the material world ... social relationships" (Kemmis et al., 2014: 4) to encompass where and how social encounters occur.

It should be noted that a strong interdependency exists between the five key dimensions, and that they do not stand unaffected by each other. For example, entities in a setting, such as a person as part of a specific socioeconomic-cultural community's sensemaking, are influenced by the identity of that community. This, in turn, refers to the dimension of interrelatedness.

Schatzki et al. (2005: 55) make this point, by clearly showing the interdependency: "The actions people intend knowingly to perform are those that make sense to them to perform. I call the state of affairs that action makes sense to someone to do practical intelligibility."

Boud and Brew (2017: 81) refer to "relationality" as sets of "social interactions, connections, arrangements and relationships". Relationality, as with interrelatedness, encompasses the human and nonhuman relations, thus the material or object and the agent or body in a practice. The coconstruction of the practice is mediated through this relationality.

For the sake of unpacking a reimagination of collaboration as a social practice, the key dimensions are considered separately, before the interdependency and relationalities are added.

\subsubsection{Social practice dimension 5: Structuring tensions}

Structuring tensions are those social practice dimensions that are continuously encountered through the relational engagement with literature and theory. These are the elements, it is argued, that hold the practice in suspension or hold the tension. They pull a practice together and make it identifiable. Healey (2003: 103) refers to the "driving forces ... government ... the impact of global conditions ...the local manifestation of wider social and environmental movement ..." to explain the appearance of what is labelled, in this instance, as structuring tensions. All of these driving forces occupy a specific context and scale and have particular consequences for power relations and consensus. From there, the sub-dimensions of power, consensus, context and scale.

It should be noted that the above structuring tensions' sub-dimensions (power, consensus, context, and scale) are interwoven to such an extent that it is futile to have a discussion around one without the others. This is illustrated throughout the literature. For instance, Schatzki (1988) understands the setting not to be only its physical aspect, but to include, for example, a change in attitude or shifts in power relations.

Power is a dynamic of the 'real' planning world that manifests in what Van den Broeck (2018: 33) describes as "tensions between public and private interests, power structures, conflict". A marketdriven and neoliberal environment concentrates its attention on private interests, which are in direct conflict with the planning philosophy of the 'greater good'.

Watson (2014: 64) also raises awareness of the ever-present nature of power when she describes relationships of co-production as "power operates in and through such relationships". This quality of power to 'sit in the cracks' is picked up by Geels and Schot (in Schatzki 2011: 19) when they refer to "landscape pressure". The authors recognise the positive quality of power, in this instance, as a vehicle for change and suggest that, if no shifts in "external landscape pressure" occur, repetition or reproduction of a practice (or part of a practice) is 
possible. It is contended in this article that landscape pressure is driven by power relations and is essential for reimagining a foundational concept such as collaboration.

Power is also associated with negative qualities such as inequality and lack of social redress. A strive for consensus is offered as a potential offset for destructive power relations. Van den Broeck (2018: 39) suggests "reflective argumentation" as a tool to use in developing consensus (as part of judgement and decision-making) in complex and changing realities.

It is recognised that numerous criticisms exist towards the Habermasian position of consensusseeking as opposed to the Foucaultian location of conflict and power (Flyvjberg, 2000). Flyvjberg (2000: 3) explains Habermas' consensus as "power neutrality" and Foucault's understanding as not meaning an "absence of power" (Flyvjberg, 2000:11). What is of relevance for both this article and the conceptual framework it proposes, is the foregrounding of consensus as a sub-dimension that needs to be interrogated in the collaborative process. The fact that emphasis is placed on it creates an opportunity to engage with what it should mean and how it should be applied in a specific collaborative endeavour.

The final element in the structuring tensions dimension is context and scale. Considering context and scale simultaneously seems unavoidable because of its strong relationality. Schatzki (2011: 18) refers to "place, size and scale" and references Latour who mentions "scale, space and contextualis[ation]" as elements in a practice that are 'produced' simultaneously and in relation to each other. In urban planning, context influences scale and is simultaneously influenced by scale.

A key text from Kemmis et al. (2014: 33) provides an opening into engaging with 'context and scale': "[T]he way a practice unfolds or happens is always shaped by the conditions that pertain to a particular site at a particular time".
It is contended that the coming together of knowledge, bodily performance, mental activities, objects, communication, motivation, and attitude cannot necessarily be predetermined, and space should be left for natural emergence. The context, thus the site of the social practice, is provided by the incidental, responsive and surprising. Context and scale are understood as instrumental in allowing and supporting a practice to develop, to change and to "unfold" (Kemmis et al., 2014).

\subsection{Iteration 2: Infusing collaborative planning theories}

This section provides an abbreviated account (by building on section 3.1) of infusing the social practice dimensions with collaborative planning theories. It should be noted that the intention is not to explore the deficiencies that might exist in collaborative planning theory, but to enhance the social practice dimensions with ideas, concepts and thought from collaborative planning theories.

Sager (2012) provides an important contribution to the argument of restoring collaborative planning theory as an accepted critical theory after numerous criticisms of the stagnation and the relevance of collaborative planning theory. He attempts to "make collaborative planning theory less vulnerable and more robust in the face of accusations that this planning theory serves other interests than intended" (Sager, 2012: xix). He specifically refers, in this instance, to the imbalances in power relations and the neoliberal agenda as influences and, to some extent, dictating the outcome of collaborative planning theory.

\section{Collaborative planning theories} have been instrumental in shaping urban planning practice. Notable theorists are Innes (1996) and Innes and Booher (1999; 2002; 2010) around the network society, power and the knowledge assumptions of consensus-building; Healey $(1997 ; 2003)$ and the focus on collaborative planning and the communicative turn; TewdwrJones and Allmendinger (1998) and their critique of Habermasian collaborative planning theory and the inadequacies in understanding communicative rationalities.

All these theorists provide slight variations in their arguments, but most of them share the following as similarities of collaborative planning, as adapted from Healey (1997: 5): "Collaboration is a normative position taken in planning that attempts to share power by focusing on consensus-building through communicative processes."

Although the above provides a workable understanding of collaborative planning, numerous reviews and criticisms need to be considered. Tewdwr-Jones and Allmendinger (1998: 1975), for example, warn that "collaborative planning theory fails to incorporate adequately the peculiar political and professional nuisances that exist in planning practice".

Healey (1997) raises a number of criticisms that should be considered. These are: the importance of context and how that shapes an understanding of collaboration; the impact that power has on the identity of collaboration, and the role of process in collaboration or what Reckwitz (2002) calls routinised relations or Schatzki's (1988) reference to actions or chains of actions captured in process.

Allmendinger (2017) provides one of the latest conceptualisations through communicative rationalities and understanding collaborative planning within the backdrop of the neoliberalisation of cities. He warns that the main reason for the reluctance of translating collaborative planning theory into practice sits with the "loss of power for planners" (Allmendinger, 2017: 30). To this point, Roy (2015: 61) makes reference to collaborative governance and its "many limitations or rather manipulations" to indicate the many ways in which collaboration 
can be manoeuvred and exploited through power dynamics.

Healey's understanding of collaborative planning as "resolv[ing] around practical concerns relating to understanding and action" offers a practice understanding, so to speak (Harris, 2002: 23). In contrast to Healey's widely accepted understanding, critique is offered by Allmendinger when providing an understanding of collaborative planning as a "world view" (Harris, 2002: 23), thus influencing a way of being. These contrasting opinions influenced the selection of authors to consider in the second relational reading iteration (see Table 2) to include as many positions as possible.

\section{EMERGENCE OF A 'COLLABORATION AS A SOCIAL PRACTICE' CONCEPTUAL FRAMEWORK}

Developing a conceptual framework is a complex and iterative process. As such, a number of qualifications need to be made. First, reflecting on the iterative nature of what Verster, Collett and Van den Berg (2019: 153) refer to as the "activity of RE- ... RE-reading, RE-thinking, RE-positioning, REturning". The 'activity of RE-' can, of course, not be fully captured in a linear article such as this. Thus, the full extent of the complexity of a relational reading is not captured and presented in this article, but only a condensed version. For purposes of building the framework, an over-simplified three-step process is described and implemented as step 1: emergence of key social practice dimensions (Table 1); step 2: enrichment of social practice dimensions with collaborative planning theories (Table 2), and step 3: captures the findings of steps 1 and 2 in the form of dimensions and subdimensions (Figure 1 and Table 3 ).

A second qualification is to note that what is presented in this article is by no means considered an exhaustive engagement with collaborative theorists or social practice theorists for that matter. Snyder's (2019) suggestion of an integrative review approach when engaging literature, text or theory of mature topics was taken to heart in this article. An integrative review process is described as "to overview the knowledge base, to critically review and potentially re-conceptualize, and to expand on the theoretical foundation of the specific topic as it develops" and "should not be descriptive or historical but should preferably generate a new conceptual framework or theory" (Snyder, 2019: 336).

\subsection{Step 1: The emergence of key social practice dimensions}

Table 1 represents Step 1: Emergence from a relational reading of social practice theories in the context of collaboration. Table 1 shows that the five new key dimensions emerged from the theories read and their combined explanation in terms of collaboration.

\subsection{Step 2: Enrichment of key social practice dimensions with collaborative planning theories}

Table 2 represents the enrichment of the key social practice dimensions with a selection of collaborative planning theories or theoretical positionings, in order to reveal emerging sub-dimensions.

The process of developing the sub-dimensions was continuous with both the discussions in sections 3.1 and 3.2 influencing the final sub-dimensions presented on the CoSoP framework in Figure 1. This is in line with the emergence quality of the method of a relational reading. To illustrate the fact that the subdimensions cannot (and should not) be traced back to only one origin, the following: some sub-dimensions were revealed during the engagement with social practice theory, for example, the sub-dimension 'sayings and doings' as part of the dimension of 'relational actions' can be traced back to Schatzki (2005).

Some sub-dimensions are directly identifiable from the original text in Table 2, for example 'relational goods' (Sager, 2012) under the dimensions of 'relational actions', while others have a level of interpretation, for example 'acts of communication' under the dimension of 'entities' resonates with both

Table 1: $\quad$ Five new key dimensions

\begin{tabular}{|l|l|l|l|}
\hline $\begin{array}{l}\text { Theoretical underpinning } \mathbf{1} \\
\text { (Schatzki) }\end{array}$ & $\begin{array}{l}\text { Theoretical underpinning } \mathbf{2} \\
\text { (Reckwitz) }\end{array}$ & New key dimensions & Combined explanation \\
\hline Actions or chains of action & Routinised relations & $\begin{array}{l}\text { RELATIONAL ACTIONS } \\
\text { (that which you 'do') }\end{array}$ & $\begin{array}{l}\text { The actions that people in the practice regularly perform } \\
\text { together. Those actions and chains of actions that become a } \\
\text { habit within a practice. Knowing 'how to', which Schatzki refers } \\
\text { to as the 'sayings and doings' (2005) in a practice. }\end{array}$ \\
\hline Entities in setting & Indispensable resources & $\begin{array}{l}\text { ENTITIES } \\
\text { (that which you 'use') }\end{array}$ & $\begin{array}{l}\text { Those entities }{ }^{5} \text { that enable and/or limit the development and } \\
\text { performance of/in the practice. These elements can be people, } \\
\text { events and objects, physical and non-physical entities. }\end{array}$ \\
\hline Intelligibility-determining factors & Objects, forms of behaviour & $\begin{array}{l}\text { SENSE-MAKING } \\
\text { (why you do and use) }\end{array}$ & $\begin{array}{l}\text { That which influences and determines what makes sense to do } \\
\text { and how to be. This is more than 'knowing that' and refers to } \\
\text { "understanding the world" (Reckwitz, 2002: 253). }\end{array}$ \\
\hline Interrelations & $\begin{array}{l}\text { Patterns of bodily behaviour and } \\
\text { bodily and mental agents }\end{array}$ & $\begin{array}{l}\text { INTERRELATEDNESS } \\
\text { (how it relates/works } \\
\text { together) }\end{array}$ & $\begin{array}{l}\text { How does all the above work together or work against } \\
\text { each other? The nature of all the interrelationships } \\
\text { (body-body-object-object) }\end{array}$ \\
\hline $\begin{array}{l}\text { Emerged from engaging with } \\
\text { collaborative theories. }\end{array}$ & STRUCTURING TENSION & $\begin{array}{l}\text { Those principal elements that hold the tension in a practice. } \\
\text { Issues such as power, consensus, context and scale are } \\
\text { considered major influences on the fundamental nature of a } \\
\text { collaborative practice. }\end{array}$ \\
\hline
\end{tabular}

5 Reference is made, in this instance, not only to physical entities, but also to knowledge and understanding/interpretation that is captured in bodily and mental activities (Reckwitz, 2002). 
Tewdwr-Jones and Allmendinger's (1998) concept of mediatory tools and Innes and Booher' (2002) idea of authentic dialogue.

Even the dimension of 'structuring tensions' and its subsequent sub-dimensions emerged from a non-linear, unpredictable process during the infusion of collaborative theory, thus after step 2. It was found that power, reference to consensus, and context and scale were submerged in all aspects of collaboration and as such were identified as sub-dimensions.

Overall, as can be noted from the above discussion, a relational reading of text is a complex and entangled process not unlike the reality confronting contemporary urban planning.

\subsection{Step 3: 'Collaboration as a Social Practice' (CoSoP) framework}

Figure 1 represents Step 3: A simplified version of the CoSoP framework with the five key dimensions and sub-dimensions as it emerged through two iterations of a relational reading.

The CoSoP framework in

Figure 1 could be used and developed continuously to reflect different contexts, understandings and experiences. For example, placed on the same row in the top half of the structure, the 'RELATIONAL ACTIONS' could include 'actions taken together' such as organised activities \& actions, and community engagement; 'sayings $\&$ doings' such as practice habits, professional attitude; 'relational goods' such as sense of belonging, professional identity, solidarity, and ethic of care. 'ENTITIES' could focus on 'acts of communication' such as mediatory tools, and forms of dialogue; 'materials \& objects' such as cultural-socio-economic-political material resources and artefacts; 'knowledge \& understanding' such as discourse, and whose knowledge; 'people' such as sets of actors, role players, and special interest groups; 'events' such as new social circumstances, and professional bodies, and 'context' such as situatedness. 'SENSEMAKING' could reflect on the 'influences \& controls' such as politics, professional identity, beliefs and values, planning mechanisms, and technological advances;

Table 2: Central themes emerging from a relational reading of social practice dimensions with a selection of collaborative theory

\begin{tabular}{|c|c|c|c|c|}
\hline \multicolumn{5}{|c|}{ Social practice dimensions } \\
\hline Theoretical positioning & Relational actions & Entities & Sense-making & Interrelatedness \\
\hline $\begin{array}{l}\text { Tewdwr-Jones \& } \\
\text { Allmendinger (1998) } \\
\text { Communicative } \\
\text { rationality }\end{array}$ & $\begin{array}{l}\text { *"A social group orientate their } \\
\text { actions according to a set of } \\
\text { predefined common values" } \\
(1998: 1976) .\end{array}$ & $\begin{array}{l}\text { *What are the mediatory tools if } \\
\text { consensus is not reached? } \\
\text { *Link between resources and the } \\
\text { ability to 'speak', thus voice. }\end{array}$ & $\begin{array}{l}{ }^{*} \text { The same view of the } \\
\text { importance of collaboration } \\
\text { as a value attribute is not held } \\
\text { by all. }\end{array}$ & $\begin{array}{l}\text { *Political and professional nuances } \\
\text { that exist in planning practice. } \\
\text { *Centrality of the life world, thus } \\
\text { underplaying the dominance of } \\
\text { the 'expert'. }\end{array}$ \\
\hline $\begin{array}{l}\text { Innes \& Booher (2002) } \\
\text { Network power }\end{array}$ & $\begin{array}{l}{ }^{*} \text { Consensus-building as a form } \\
\text { of collaborative planning. } \\
\text { *“Networked patterns of } \\
\text { actions" (2002:225). }\end{array}$ & $\begin{array}{l}{ }^{*} \text { Authentic dialogue as acts of } \\
\text { communication. } \\
\text { *Network power emerges from } \\
\text { consensus-building }\end{array}$ & $\begin{array}{l}\text { *"Diversity and } \\
\text { interdependence amongst } \\
\text { groups" (2002:224) as } \\
\text { influence. } \\
\text { *Strong link between power } \\
\text { and collaboration. }\end{array}$ & $\begin{array}{l}\text { Conditions to govern } \\
\text { relationships of agents: DIAD } \\
\text { - diversity, interdependence, } \\
\text { authentic dialogue. }\end{array}$ \\
\hline $\begin{array}{l}\text { Healey }(2003 ; 2007) \\
\text { Normativity of } \\
\text { collaborative planning }\end{array}$ & \begin{tabular}{|l|} 
*Consensus-building as an \\
offset for destructive power. \\
*Which processes are available/ \\
used to manage collective \\
affairs of social groups? \\
*Sensitivity towards culturally \\
diverse values. \\
*"Power of agency" (2003: 105) \\
as a relational good.
\end{tabular} & $\begin{array}{l}\text { *Situated dynamics, different } \\
\text { sets of actors. } \\
\text { *Power of agency. } \\
\text { *Who are the role players? } \\
\text { *Aim is not to neutralise power. } \\
\text { *Giddens - 'power over' } \\
\text { others and 'power to' make } \\
\text { things happen. }\end{array}$ & \begin{tabular}{|l|} 
*Planning systems provide \\
mechanism for mediating \\
among conflicting interests at \\
various scales. \\
${ }^{*}$ Institutional environment \\
as control. \\
${ }^{*}$ Consensus-building. \\
${ }^{*}$ Social situatedness influences \\
what makes sense.
\end{tabular} & $\begin{array}{l}\text { *Structuring forces that } \\
\text { influence actions. } \\
\text { *Different kinds of interactions, } \\
\text { different sets of actors. } \\
\text { *Relational perspective - Power as } \\
\text { relation not a 'thing'. } \\
\text { *Social relations are } \\
\text { driven by a multitude of } \\
\text { co-constructuring forces. }\end{array}$ \\
\hline $\begin{array}{l}\text { Sager (2012) } \\
\text { Communicative } \\
\text { planning theory }\end{array}$ & $\begin{array}{l}\text { *"Relational goods" (2012: } 27) \text {. } \\
\text { What are the relational goods } \\
\text { that the practice shares and } \\
\text { that are used by all actors in } \\
\text { the practice? }\end{array}$ & $\begin{array}{l}\text { The role of stakeholders can be } \\
\text { destructive in using a dominant } \\
\text { social position (2012: xvii). What } \\
\text { knowledge and understanding } \\
\text { are present to counter this? }\end{array}$ & $\begin{array}{l}\text { *To what extent does the } \\
\text { quality of collaborative planning } \\
\text { to be "consensus-seeking" } \\
\text { (2012: xii) influence the nature } \\
\text { of the collaborative persona } \\
\text { and endeavour? }\end{array}$ & $\begin{array}{l}\text { *The relationship between } \\
\text { knowledge, actions and power } \\
(2012: 30)\end{array}$ \\
\hline $\begin{array}{l}\text { Watson (2014) } \\
\text { Co-production }\end{array}$ & $\begin{array}{l}\text { *What are the reasons for } \\
\text { co-production, for example: } \\
\text { building social capital, } \\
\text { service provision? } \\
\text { *Which are the activities that } \\
\text { are ongoing and repeated? }\end{array}$ & $\begin{array}{l}\text { *What are the new } \\
\text { circumstances and challenges } \\
\text { to which collaborative planning } \\
\text { needs to respond? }\end{array}$ & $\begin{array}{l}\text { *"How the starting assumptions } \\
\text { reflect the very different } \\
\text { contexts in which they } \\
\text { (co-production processes) are } \\
\text { taking place" (2014: } 64) \text {. }\end{array}$ & $\begin{array}{l}\text { *The importance of context and how } \\
\text { there cannot be one single global } \\
\text { perspective (2014: } 62) \text {. } \\
\text { *"How power operates in and } \\
\text { through ... relationships" (2014: 64). }\end{array}$ \\
\hline $\begin{array}{l}\text { Emerging } \\
\text { sub-dimensions }\end{array}$ & $\begin{array}{l}\text { Actions taken together } \\
\text { Relational goods } \\
\text { The centrality of consensus- } \\
\text { building and sharedness } \\
\text { influences the actions } \\
\text { taken together. } \\
\text { Reason for doing determines } \\
\text { forms/levels of collaboration. }\end{array}$ & $\begin{array}{l}\text { Acts of communication } \\
\text { Context } \\
\text { Communication is influenced } \\
\text { by the availability of material } \\
\text { resources and objects as well as } \\
\text { knowledge and understanding. } \\
\text { Context governs the identity } \\
\text { of collaboration. }\end{array}$ & $\begin{array}{l}\text { Influences and controls } \\
\text { Situatedness } \\
\text { Professional identity influenced } \\
\text { by numerous controls. } \\
\text { Context is understood to be } \\
\text { driven by shared values. }\end{array}$ & $\begin{array}{l}\text { Commonality of collective } \\
\text { relationality } \\
\text { The identity of the agent is } \\
\text { immersed in the collective. } \\
\text { Relationality is defined by } \\
\text { sharedness, motivation, } \\
\text { power relations, shared values } \\
\text { and situatedness. }\end{array}$ \\
\hline
\end{tabular}




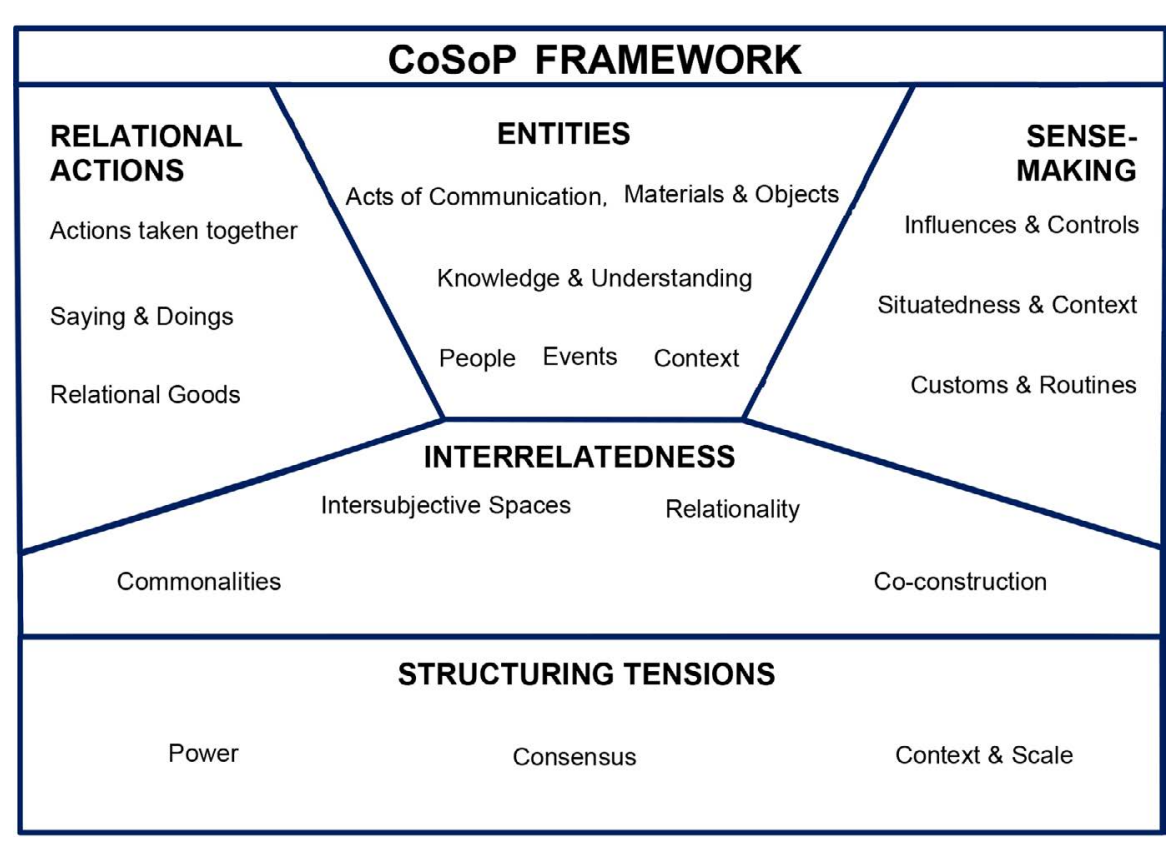

Figure 1: The CoSoP framework

'situatedness \& context' such as language used, power structures, and meaning-making determinants, and 'customs \& routines' such as modelling and mentorship, institutional structures, and moral awareness (social ought to).

Placed in the centre of the framework and connecting all the dimension(s) and sub-dimensions in the top and bottom row, 'INTERRELATEDNESS' could consider 'commonalities' such as that which is common in groups, and identity; 'Intersubjective spaces' such as where people encounter each other, and how social encounters occur; 'relationality' such as sets of interactions, connections, and arrangements, and 'co-construction' such as bodyobject relation, lived experiences, and bodies in a certain way.

Placed on the bottom as the core foundation of the structure, 'STRUCTURING TENSIONS' could describe 'power' such as tensions between different interests, positive power relations, and landscape pressures; 'consensus' such as offset for destructive power relations, negotiating complex and changing realities, and reflective argumentation, and 'context \& scale' such as global conditions, social movements, conflict, negotiation, the greater good, and change.

\section{CONCLUSION}

Watson's (2014: 63) sentiment that "approaches to planning commonly in use are often outdated or were developed with very different socio-spatial conditions in mind" inspired the need to focus research on new ways of knowing, understanding and being in the world. To realise such new ways, different methodological choices need to be considered. A relational reading of text is introduced in this article as a method to provide an opportunity for new emergences.

The outcome of a relational reading of social practice theories and collaborative planning theories is presented in the CoSoP framework. The CoSoP framework provides an opportunity for practitioners and students of urban planning to think with and through some of the complexities of collaboration that might typically be obscured. Purcell (2009) makes an interesting point that the neoliberal urban agenda is using specifically this obscuring or diluting of the seemingly 'democratic' decision-making practices, in order to shift power away from citizens. It is contended that this article provides a tool to engaging with and foreground such complexities of collaboration.

The article makes two original contributions to existing literature.
First, a methodological contribution by unpacking a relational reading of text as a research method to engage text in a 'careful' manner without presupposing and making demands on text by asking specific questions. Secondly, by offering a conceptual framework that provides a disentangled vantage point of a complex professional value attribute.

This framework, it is argued, has the potential to be used in a number of ways. First, it can serve as a forward-looking instrument to engage with collaborators at the initial stages of the collaborative process. It can capture and highlight existing social capital and strengths and identify potential areas of limitation and weakness. This first engagement with collaborators around the process of collaboration sets the tone for and can be considered to be influential in developing the needed buy-in and support from all role players.

Secondly, the CoSoP framework also has the potential to be a retrospective instrument. It can be used as a tool to reflect on collaborative endeavours, in order to identify gaps for future reference and action. This characteristic of the CoSoP framework of both being forwardlooking and retrospective amplifies its capacity to enrich planning activities.

In conclusion, collaboration is considered one of the central professional value attributes of an urban planner and should, as such, be continuously examined for its relevance. This article proposes a renewed entry point in this process of challenging relevance by framing collaboration as a social practice.

\section{REFERENCES}

ALLMENDINGER, P. 2017.

Planning theory. 3rd edition. London: Palgrave. https://doi. org/10.1057/978-0-230-38004-2.

BARAD, K. 2007. Meeting the universe halfway: Quantum physics and the entanglement of matter and meaning. Durham, NC: NC Duke University Press. https://doi.org/10.1215/9780822388128. 
BARAD, K. 2014. Diffracting diffraction: Cutting together-apart. Parallax, 20(3), pp. 168-187. https://doi.org/10.1080/13 534645.2014.927623.

BOUD, D. \& BREW, A. 2017. Learning to teach as the development of practice. In: Leibowitz, B., Bozalek, V. \& Khan, P. 2017. Theorising learning to teach in higher education. New York: Routledge, pp. 77-92.

CARMON, N. 2013. The profession of urban planning and its societal mandate. Policy, Planning and People: Promoting Justice in Urban Development, pp. 13-31. https://doi. org/10.9783/9780812207965.

COSTANDIUS, E. 2019. Fostering the conditions for creative concept development. Cogent Education, 6(1), pp. 1-10. DOI: https://doi.org/10.1080/2 331186X.2019.1700737.

DONATI, P. 2010. Birth and development of the relational theory of society: A journey looking for a deep 'relational sociology'. [Online]. Available at: <https://www.relationalstudies.net> [Accessed: 20 March 2018].

FLYVJBERG, B. 2000. Ideal theory, real rationality: Habermas versus Foucault and Nietzsche. Paper presented at the Political Studies Association's 50th Annual Conference, 10-13 April, London, UK. The Challenges for Democracy in the 21st Century, London School of Economics and Political Science. https://doi. org/10.2139/ssrn.2278421.

FLYVBJERG, B., RICHARDSON, T., ALLMENDINGER, I.P. \& TEWDWRJONES, M. 2002. Planning and Foucault. In: Allmendiger, P. \& TewdwrJones, M. (Eds), Planning futures: New directions for planning theory. London: Routledge, pp. 44-62.

FRIEDMAN, J. 2000. The good city: In defense of utopian thinking. International Journal of Urban and Regional Research, 24(2), pp. 460-472. https://doi. org/10.1111/1468-2427.00258.

GERGEN, K. 2008. Writing as relationship. [Online]. Available at: $<$ https://taoslearning.ning.com/groups2/ global-relational-research-network/ resources> [Accessed: 22 March 2018].
GOLDFRANK, B. \& SCHRANK, A. 2009. Municipal neoliberalism and municipal socialism: Urban political economy in Latin America. International Journal of Urban and Regional Research, 33(2), pp. 443-462. https://doi. org/10.1111/j.1468-2427.2009.00834.x.

HARAWAY, D. 1992. The promises of monsters: A regenerative politics for inappropriate/d others. In: Grossberg, L., Nelson, C. \& Treichler, P.A. (Eds). Cultural studies. New York: Routledge, pp. 295-337.

HARRIS, N. 2002. Collaborative planning: From theoretical foundations to practice forms. In: Allmendiger, P. \& Tewdwr-Jones, M. (Eds). Planning futures: New directions for planning theory. London: Routledge, pp. 21-43.

HEALEY, P. 1997. Collaborative planning: Shaping places in fragmented societies. Macmillan International Higher Education. South Africa: Red Globe Press.

HEALEY, P. 2003. Collaborative planning in perspective. Planning Theory, 2(2), pp. 101-123. https://doi. org/10.1177/14730952030022002.

HEALEY, P. 2007. Urban complexity and spatial strategies: Towards a relational planning for our times. New York: Routledge. https://doi. org/10.4324/9780203099414.

ILLERIS, K. 2009. Contemporary theories of learning: Learning theorists ... in their own words. New York: Routledge. https://doi. org/10.4324/9780203870426.

INNES, J. 1996. Planning through consensus building: A new view of the comprehensive planning ideal. Journal of the American Planning Association, 62(4), pp. 460-472. https://doi. org/10.1080/01944369608975712.

INNES, J. \& BOOHER, D. 1999.

Consensus building as role playing and bricolage: Towards a theory of collaborative planning. Journal of the American Planning Association, 65(1), pp. 9-26. https://doi. org/10.1080/01944369908976031.

INNES, J. \& BOOHER, D. 2002. Network power in collaborative planning. Journal of Planning Education and Research, 21(3), pp. 221-236. https://doi. org/10.1177/0739456X0202100301.
INNES, J. \& BOOHER, D. 2010.

Planning with complexity: An introduction to collaborative rationality for public policy. New York: Routledge. https://doi. org/10.4324/9780203864302.

KELLY, J. 2002. Collaborative learning: Higher education, interdependence, and the authority of knowledge by Kenneth Bruffee: A critical study. Journal of the National Collegiate Honours Council. Online Archive 82. [Online]. Available at: $<$ http://digitalcommons.unl.edu/ nchcjournal/82/?utm> [Accessed: 22 January 2017].

KEMMIS, S., WILKINSON, J., EDWARDS-GROVES, C., HARDY, I. GROOTENBOER, P. \& BRISTOL, L. 2014. Changing practices, changing education. Singapore: Springer. https:// doi.org/10.1007/978-981-4560-47-4.

LAW, J. 2004. After method: Mess in social science research. London: Routledge. https://doi. org/10.4324/9780203481141.

MCCAN, E. 2001. Collaborative visioning or urban planning as therapy? The politics of public-private policy making. The Professional Geographer, 53(2), pp. 207-218. https://doi. org/10.1111/0033-0124.00280.

MURRIS, K. \& BOZALEK, V. 2019. Diffraction and response-able reading of texts: the relational ontologies of Barad and Deleuze. International Journal of Qualitative Studies in Education, 32(7), pp. 872-886, DOI: https://doi.org/10.1080/09518398.2019 .1609122.

ORLIKOWSKI, W. \& SCOTT, S. 2015. Exploring material-discursive practices. Journal of Management Studies, 52(5), pp. 697-705. https://doi.org/10.1111/ joms.12114.

PARNELL, S. \& ROBINSON, J. 2012. (Re)theorizing cities from the Global South: Looking beyond neoliberalism. Urban Geography, 33(4), pp. 593-617. https://doi. org/10.2747/0272-3638.33.4.593.

PURCELL, M. 2009. Resisting neoliberalization: Communicative planning or counter-hegemonic movements? Planning Theory, 8(2), pp.140-165. https://doi. org/10.1177/1473095209102232. 
RECKWITZ, A. 2002. Towards a theory of social practices: A development in culturalist theorizing. European Journal of Social Theory, 5(2), pp. 243-263. https://doi. org/10.1177/13684310222225432.

ROY, P. 2015. Collaborative planning - A neoliberal strategy? A study of the Atlanta BeltLine. Cities, 43, pp. 59-68. https://doi.org/10.1016/j. cities.2014.11.010

SAGER, T. 2012. Reviving critical planning theory: Dealing with pressure, neo-liberalism and responsibility in communicative planning. New York: Routledge. https://doi. org/10.4324/9780203104187.

SCHATZKI, T. 1988. The nature of social reality. Philosophy and Phenomenological Research, 49(2), pp. 239-260. https://doi. org/10.2307/2107975.

SCHATZKI, T. 2002. The site of the social: A philosophical account of the constitution of social life and change. University Park, PA: The Pennsylvania State University Press.

SCHATZKI, T. 2005. Peripheral vision: The sites of organizations. Organization Studies, 26(3), pp. 465-484. https://doi. org/10.1177/0170840605050876

SCHATZKI, T. 2011. Where the action is (on large social phenomena such as sociotechnical regimes). Sustainable Practices Research Group, Working Paper no. 1, pp. 1-31.

SCHATZKI, T., KNORR-CETINA, K. \& VON SAVIGNY, E. 2005. The practice turn in contemporary theory. London: Routledge. https://doi. org/10.4324/9780203977453.

SIMON, G. 2012. Relational ethnography: Writing and reading in research relationships. Forum: Qualitative Social Research, 14(1), Art. 4. http://nbn-resolving.de/ urn:nbn:de:0114-fqs130147.

SNYDER, H. 2019. Literature review as a research methodology: An overview and guidelines. Journal of Business Research, 104, pp. 333-339. https://doi. org/10.1016/j.jbusres.2019.07.039.

\section{TEWDWR-JONES, M. \&}

ALLMENDINGER, P. 1998.

Deconstructing communicative rationalities: A critique of Habermasian collaborative planning. Environment and Planning, 30(11), pp. 1975-1989. https://doi.org/10.1068/a301975.
TASAN-KOK, T. \& ORANJE, M. (Eds). 2018. From student to urban planner. Young practitioners' reflections on contemporary ethical challenges. New York: Routledge. https://doi. org/10.4324/9781315726854.

VAN DEN BROECK, J. 2018. Challenges of planning practice and profession: To what extent are young planners able to intervene? In: Tasan-Kok, T. \& Oranje, M. (Eds). From student to urban planner. Young practitioners' reflections on contemporary ethical challenges. New York: Routledge. https://doi. org/10.4324/9781315726854-3.

VERSTER, B., COLLETT, K. \& VAN DEN BERG, C. 2019. Creative meaning-making through a multimodal, interdisciplinary exploration: Lessons for higher education curriculum enhancement. Alternations Special Edition 27, pp. 139-160. https://doi. org/10.29086/2519-5476/2019/sp27a6.

WATSON, V. 2014. Co-production and collaboration in planning The difference. Planning Theory \& Practice, 15(1), pp. 62-76. http://dx.doi. org/10.1080/14649357.2013.866266.

WENGER, E. 1998. Communities of practice: Learning, meaning, and identity. New York: Cambridge University Press. https://doi. org/10.1017/CBO9780511803932 